\title{
Trade Liberalization, Domestic Trade Policies and the Failure of Reducing Poverty: The Case of Indonesia
}

\author{
I Gusti Ngurah Parikesit Widiatedja \\ Melbourne Law School, Australia \\ ngurahparikesit@gmail.com
}

Published: 25/02/2021

\begin{abstract}
How to cite:
Widiatedja, I, G, N, P. 2021. Trade Liberalization, Domestic Trade Policies and the Failure of Reducing Poverty: The Case of Indonesia. Sociological Jurisprudence Journal. Volume 4 Issue 1. Page 6 - 12. https://doi.org/10.22225/scj.4.1.2289.6-12

Abstract

The existence of international trade has provided important benefits for reducing poverty. Many countries then have concluded trade agreements, to reach this goal by committing trade liberalization. The relatively high number of poverty has raised some concerns, questioning the effectiveness of trade liberalization. Putting Indonesia as a case study, this article weighs the role of trade liberalization and domestic trade policies in reducing poverty. This article argues that the existence of domestic trade policies is more significant than trade liberalization. The unfair practices, corruption, and the overwhelming spirit of national interest that colour domestic trade policies, contribute to the failure of reducing poverty instead of trade liberalization.
\end{abstract}

Keywords: Trade Liberalization, Domestic Trade Policies, Reducing Poverty, Indonesia

\section{INTRODUCTION}

The existence of international trade has provided important benefits, including alleviating poverty, increasing $\mathrm{GDP}^{1}$, and reducing unemployment ${ }^{2}$. Almost all trade agreements (both bilateral, regional, and multilateral) then put these goals in their primary objectives. The preamble of the World Trade Organization (WTO agreement) shows how the elimination of trade distortion is the prerequisite in reaching the objectives of intensifying 'standards of living' and safeguarding 'full employment'. In Australia-China FTA, the reduction of trade distortions, including investment flows will 'create new opportunities for employment and to improve the living standards of their peoples' 4 .

The relatively high number of poverty has raised some concerns, questioning the contribution of trade liberalization across the globe. In 2015, United Nations Development Program (UNDP) denoted an inequality concerning human development ${ }^{5}$, particularly when most countries reached a medium level, Sub Saharan Africa still experienced with a low-level of human development ${ }^{6}$. In addition, 94 percent of the income of the world only is only circulated to 40 percent of world's population ${ }^{7}$. Some experts then show their concerns, explaining that trade liberalization have negatively affected environment ${ }^{8}$ and cultural value, and heritage?

Indonesia has been involving in the General Agreement on Tariffs and Trade (GATT) since 24 February 1950, and the WTO since 1 January $1995^{10}$. Indonesia was ardently joined in groups that encouraged specific trade issues during the WTO negotiations, such as the Cairns Group $^{11}$, the G-20 ${ }^{12}$, and the G-33 ${ }^{13}$. In PTA, Indonesia has concluded agreements with other WTO members, such as Bulgaria (2004) ${ }^{14}$, and with non-WTO members, such as Uzbekistan $(2008)^{15}$. On behalf of ASEAN, Indonesia has concluded PTAs with China $(2002)^{16}$, India 
$(2003)^{17}$, Korea $(2005)^{18}$, Japan $(2008)^{19}$, and Australia and New Zealand $(2009)^{20}$.

However, there has been a continuous protest in Indonesia, doubting the contribution of trade liberalization for Indonesia's growth and development. While Indonesia (Bali) became a host of WTO annual meeting in Bali, activists showed their disagreement in the implementation of trade liberalization. They insisted that Bali Package had no benefits for Indonesia, and only marginalised farmers, professionals, and civil servants, putting Indonesia as a victim of trade policies ${ }^{21}$.

In 2018, when Indonesia hosted World Bank and IMF annual meeting, the issues are somewhat similar. Indonesia's opposition criticized this event as it spends lavish amount of money while Indonesia is still in crisis $^{22}$. Furthermore, the event will have no contribution for reducing poverty, promoting labour rights, and promoting environment ${ }^{23}$.

This article aims to weigh the role of trade liberalization and domestic trade policies in reducing poverty. This article argues that the existence of domestic trade policies is more significant than trade liberalization, particularly in reducing poverty.

To begin with, this article answers the problem related to whether trade liberalisation under agreements really fails to reduce poverty. Then, it will analyse the contribution of domestic trade-related laws and policies in impeding trade agreements' goals. Putting Indonesia as a case study, this article explains the past and existing domestic trade-related laws and policies, and how they have been contributed to the poverty issue in Indonesia.

\section{DISCUSSION}

\section{Does Trade Liberalisation Really Fail to Reduce Poverty?}

This section will show current studies, explaining some criticisms of the existence of trade liberalization in alleviating poverty. Almost all trade agreements eventually issue schedule of commitment to accelerate trade liberalization. They have primary objectives to realise world's prosperity through poverty reduction. Specifically, The WTO obviously states in its preamble 'a view to raising standards of living, ensuring full employment ${ }^{24}$. Furthermore, North-American Free Trade Agreement (NAFTA) has a primary goal to reach 'new employment opportunities and improve working conditions and living standards in their respective territories ${ }^{25}$.

There are disagreements to the perspective that trade liberalisation is always positive. Muhammad Yunus, the winner of the Nobel Peace Prize, explained that income inequality was a notorious fact of trade liberalisation, showing 40 percent of world's population dominated 94 percent of the world income while 60 percent people enjoyed only six percent of the income ${ }^{26}$.

Stiglitz then analysed that the acceleration of trade liberalization without providing any 'safety nets, with insufficient reciprocity and assistance on the part of developed countries, can contribute to an increase in poverty ${ }^{27}$. Likewise, using the theory of the second best, Krugman and Obstfeld concluded that free trade can only work 'if all other markets are working properly' ${ }^{28}$. If not, it requires the intervention of government to anticipate market failure's effect ${ }^{29}$.

Some empirical studies have shown how poverty and inequality are still serious impediments to embody the prosperity. Specifically, the wage inequality remains unsolved in countries such as Colombia $^{30}$, India ${ }^{31}$, and Indonesia ${ }^{32}$. Equally, UNDP in 2015 denoted, between 1990 and 2015, when the global prevalence of extreme poverty decreased from 47 to 14 percent, the extreme poverty in SubSaharan Africa only slightly decreased from 57 to 41 percent $^{33}$.

World Bank then analysed the poverty rate in Central Asia and Europe to Africa ${ }^{34}$. It showed that from 272.4 million total population with 0.7 percent population growth, only less than 2 percent population living below $\$ 1.25$ per day in Central Asia and Europe ${ }^{35}$. Meanwhile, in Africa, from 936.3 million total population with 2.7 percent population growth, 46.8 percent Population living below $\$ 1.25$ per day ${ }^{36}$.

\section{Do Domestic Trade Policies Contribute to the Failure of Trade Liberalisation?}

Instead of blaming trade liberalisation, the following scholars will show how the existence of 
domestic trade policies determines the extent to which a country is success (or failure) to gain benefit from trade liberalization under trade agreements. Hernando De Soto (2000) analysed that inefficiencies and formalities of laws and policies in developing countries have made them fail to gain the benefits of capitalism $^{37}$. Trubek (2006) then explained how legal cultures of developing countries were highly 'formalist', causing to inconsistent enforcement, incongruous rules, and low legitimacy ${ }^{38}$.

Dee and Findlay (2009) and Abeysinghe (2014) then pointed out how domestic laws are more influential than international laws in trade in services. Trade in services' agreements predominantly focusses on 'behind the border' regulatory distortions, while those on trade in goods predominantly deal with 'at the border barriers' for instance tariffs ${ }^{39}$. Specifically, instead of tariffs, host country can impose discriminatory limitations on the movement of capital (such as limitations on foreign ownership), and a difference of domestic policies, including licensing, technical standards, and qualification compulsion ${ }^{40}$.

\section{The Case of Indonesia}

Problems on the domestic policies in Indonesia have been scrutinized by international organizations and leading scholars. World Bank (2009) revealed that the lack of coordination across different branches of government, covering the central and local level, and across different ministries at the national level in formulating and implementing laws and policies has impeded the effectiveness of the government in realising its development program ${ }^{41}$.

World Justice Project (2015) then raised three contributing factors for the shortcoming of law in Indonesia, namely "defective investigations, an ineffective correctional system, and violations to due process of law" "42. In Addition, the World Economic Forum (WEF)'s Global Competitiveness Report 2016-2017 stated that the most troublesome factors for conducting business in Indonesia were corruption and inefficiency in the bureaucracy of Indonesia ${ }^{43}$.

Daniel S. Lev (1990) revealed that harsh criticisms of the law in Indonesia have begun since 1960, especially when social injustice began to occur ${ }^{44}$. Alkostar (2000) then argued the cause of this situation because of the misuses of law enforcement ${ }^{45}$. Samekto (2008) argued that the legal crisis in Indonesia has taken place because the legal enforcement apparatus treated the law as tradable activities, as if the justice belongs only to a certain group of people so called "justice (not) for all" "46.

Analysing the legal loopholes in Indonesia, Butt (2009) found one of the reasons why the government was difficult to enforce judicial decisions ${ }^{47}$. The existence of 'surat sakti' (magic memos) has severely impeded the rule of law in Indonesia ${ }^{48}$. The Chief Justice of the Supreme Court issued these memos, instructing a lower court that a particular decision cannot be enforced ${ }^{49}$.

The regional autonomy governance is also far from perfect. Aspinall and Fealy (2003) indicated that some elements of regional autonomy had degraded the quality of governance, pointing out the lack of capacity at the regional level, the inequality between the rich and poor regions, and the massive corruption $^{50}$. Furthermore, World Bank (2009) argued that the process of regional autonomy had been coloured by the overlapping responsibilities between central and local governments and the lack of transparency ${ }^{51}$.

From those explanations, it can be concluded that domestic policies have a more influential role instead of trade liberalization. What makes the goals of trade liberalization fail is the existence of domestic policies. However, there is a possibility if trade liberalization may also contribute to that failure, particularly if the commitment of trade liberalization that has been concluded under trade agreements, haphazardly transforms into domestic policies. Juwana (2006) revealed that some policies were not realistic because the government issued these policies to follow an order of foreign countries and international financial institutions instead of people's demand ${ }^{52}$. For example, the political elite may determine that the government enacted legislation in order that Indonesia has comparable legislations to the developed country ${ }^{53}$. Besides, a foreign country or an international organisation may request Indonesia to enact a particular policy as a prerequisite before granting financial aid $^{54}$.

\section{Indonesia's Domestic Trade-Related Laws and Policies: Past Experience}

This section will explain how the past domestic trade policies have contributed to the failure of trade liberalization in reducing poverty in Indonesia. In old order under Sukarno Administration, Indonesia was reluctant in joining trade agreements. The overwhelm spirit of national interest became the main 
reason. The government conducted tariff reform to secure domestic businesses ${ }^{55}$. Further, Indonesia only approved to the decrease of tariff and non-tariff barriers executed upon export products of interest of Indonesia $^{56}$.

However, the decision to protect national interest was coloured by the corruption practice in the implementation phase. The most popular one was a corruption in the export-import licenses ${ }^{57}$. Many politicians acted business cohorts of licensees where the license was coming from discriminatory measure for prioritizing indigenous businesses ${ }^{58}$. However, this measure changed into 'behind-thescenes kickbacks paid by Chinese businessmen ${ }^{59}$. Another practice related to the fact that state-owned companies were granted a monopoly on the import of primary commodities, which was supported by state credit ${ }^{60}$. However, private companies (indigenous and Chinese firms) did not enjoy those measures and facilities ${ }^{61}$.

In New Order under Soeharto Administration, there were many types of corruption and collusion in the implementation of domestic trade policies. Kenward then elaborated these practices, including the national car project (Timor) that involved Soeharto's youngest son where the government discriminatory waived some car taxes for this project; the privatisation of excise tax collection in Bali; the bail-out of failing banks by the central bank; and the monopoly for purchasing and distributing the cloves needed by cigarette industry in Indonesia ${ }^{62}$. Almost all illegal practices occurred as a result from the strong alliances of Suharto's children and leading conglomerates, supported by strong military and political regimes ${ }^{63}$.

In this period, Indonesia was also not active in trade agreements. Only in Uruguay Round Indonesia seemed to produce trade liberalisation's commitment. In market access in goods, 95 per cent of all of Indonesia's tariff-lines, accounting 92 per cent of total imports, were bound at 40 per cent $^{64}$. However, due to the average tariff line was already around 15 per cent in 1994, Indonesia's commitment had minor impact on actual trade liberalisation ${ }^{65}$.

\section{Reformation Order and Domestic Trade Policies.}

In reformation order, the better domestic trade policies have contributed to the reduction of poverty. Under the WTO negotiations, Indonesia sustained to decrease its tariff. While in 1995 the typical tariff rate was 15.6 per cent, the typical tariff rate had lessened to 7.2 per cent in $2003^{66}$. In 2004, a tariff harmonisation program was publicized, introducing a tariff reduction (up to below 10 percent) schedule between 2004 and $2010^{67}$. According to this schedule, 94 per cent of tariff lines would have rates at or below 10 per cent by $2010^{68}$.

In 2012, the Government issued Indonesian Custom Tariff Book ('BTKI'), according to the World Custom Organization HS2012 nomenclature and the ASEAN Harmonized Tariff Nomenclature ('AHTN') ${ }^{69}$. This policy had resulted in a 10 per cent reduction in the total number of most favoured nation ('MFN') applied tariff lines ${ }^{70}$.

The implementation of trade liberalisation does not mean without any controversy. In 2011, a group of non-governmental organization (NGO) filled a complaint to the Constitutional Court of Indonesia, arguing that the Law Number 38 of 2008 on the Ratification of Charter of the Association of Southeast Asian Nations had conflicted with Indonesia's constitution. The ratification would harm the economic rights of Indonesian and it was alleged as the new colonialism and imperialism. The constitutional court, through the decision No. 33/PUU-IX/2011 finally refused the NGO's claim ${ }^{71}$.

In 2014, the government enacted Law Number 3 of 2014 on Industry. The spirit of national interest is reflected in some articles. Article 32 explains that the government may limit the export of natural resources for enhancing the value added of domestic industry ${ }^{72}$. In Law Number 7 of 2014 on Trade, article 85 explains that subject to consent of House of Representatives, the government may re-examine and withdraw international trade agreements' approval on the ground of national interest ${ }^{73}$. The law, however, did not further clarify what the meaning of cancellation, and what constitute a national interest. Therefore, this law may contravene with the provision on the termination in the Vienna Convention on the Law of Treaties of $1969^{74}$.

Some empirical studies have shown the positive impact of trade liberalisation in Indonesia. Robilliard and Park et al (2008) analysed how ASEAN-China FTA would benefit Indonesia through 
greater productivity, competition, and lower consumer prices ${ }^{75}$. A study from the Ministry of Trade of Indonesia (2011) showed how a trade agreement increased a competitiveness of Indonesian products ${ }^{76}$. By using Constant Market Share Analysis (CMSA), this study examined the competitiveness of Indonesian manufacturing products after the implementation of Indonesia- Japan FTA ${ }^{77}$. The result revealed the increase of competitiveness in the following products: fish products, cocoa, garments, and furniture $^{78}$. Nevertheless, the competitiveness of shrimp and plastic products has decreased after the implementation of this bilateral agreement ${ }^{79}$. However, ILO (2013) showed that high unemployment still occurred in Indonesia, particularly among women, the educated workforce and youth, denoting the benefits of trade liberalisation are not always equal among age, gender and groups ${ }^{80}$.

\section{III.CONCLUSION}

The existence of international trade has provided important benefits for alleviating poverty and inequality. Countries then have concluded trade agreements, to reach those goals by committing trade liberalization. The relatively high number of inequality and poverty has raised some concerns, questioning the effectiveness of trade liberalization. Putting Indonesia as a case study, this article weighs the role of trade liberalization and domestic trade policies in reducing poverty. This article argues that the existence of domestic trade policies is more significant than trade liberalization. International organizations and leading scholars have scrutinized problems on the domestic policies in Indonesia, particularly related to policy making process, the implementation of policy, and policy enforcement. From previous experience, it can be concluded that the unfair practices, corruption, and the overwhelming spirit of national interest that colour domestic trade policies, contribute to the failure of reducing poverty instead of trade liberalization.

\section{REFERENCES}

1. World Trade Organisation, World Trade Report 2011: The WTO and Preferential Trade Agreements: From Co-existence to Coherence (WTO, 2011) 12.

2. The Organization for Economic Cooperation and Development, 'The Impact of Trade Liberalisation on Jobs and Growth: Technical Note' (OECD Trade Policy Papers, 2011) 34.

3. Marrakesh Agreement Establishing the World Trade Organization, opened for signature 15 April 1994, 1867 UNTS 3 (entered into force 1 January 1995) the Preamble ('WTO').

4. Free Trade Agreement between the Government of Australia and the Government of the People's Republic of China, signed 17 June 2015, [2015] ATS 15 (entered into forced 20 December 2015), preamble [AustraliaChina FTA].

5. United Nations Development Programme, Human Development Report 2015 (UNDP,2015) 58.

6. Ibid 65.

7. Muhammad Yunus, 'Nobel Lecture', Nobel Prize (online), $2006<$ http://nobelprize.org/nobel_prizes/peace/ laureates/2006/yunus-lecture-en.html>.

8. Daniel Bodansky, Jessica C Lawrence, 'Trade and Environment' in Daniel Bethlehem et al (eds), The Oxford Handbook of International Trade Law (Oxford University Press, 2009) 508. See also I Gusti Ngurah Parikesit Widiatedja and I Gusti Ngurah Wairocana, 'The Lack of the Environmental Concern in Indonesia's Bilateral Investment Treaties' (2017) 3(3) Hasanuddin Law Review 231, 232.

9. Oliver R Goodenough, 'Defending the Imaginary to the Death?: Free Trade, National Identity, and Canada's Cultural Preoccupation' (1998) 15 Arizona Journal of International Law and Comparative Law 226.

10. World Trade Organization, 'Indonesia and the WTO' <https://www.wto.org/english/thewto e/countries e/ indonesia e.htm>.

11. The Cairns Group, Background on the Cairns Group and the WTO Doha Round <http://cairnsgroup.org/pages/ wto_negotiations.aspx>.

12. World Trade Organization, Groups in the Negotiations <https://www.wto.org/english/tratop_e/dda_e/ negotiating_groups_e.htm\#grp025>

13. Organisation for Economic Co-operation and Development, Globalisation and Emerging Economies: Brazil, Russia, India, Indonesia, China and South Africa (OECD, 2008) 151.

14. Trade Agreement between the Government of the Republic of Indonesia and the Government of the Republic of Bulgaria, signed 29 January 2004 (entered into force 3 April 2006).

15. Trade Agreement between the Government of the Republic of Indonesia and the Government of the Republic of Uzbekistan, signed 13 May 2008 (entered into force 30 September 2009).

16. Framework Agreement on Comprehensive Economic Co-operation Between the Association of South East 
Asian Nations and the People's Republic of China, signed 4 November 2002 (entered into force 1 July 2003) [ASEAN-China FTA].

17. Framework Agreement on Comprehensive Economic Cooperation Between the Republic of India and the Association of Southeast Asian Nations, signed 8 October 2003 (entered into force 1 July 2004) [ASEAN-India FTA].

18. Framework Agreement on Comprehensive Economic Cooperation Among the Governments of the Member Countries of the Association of Southeast Asian Nations and the Republic of Korea, signed 13 December 2005 (entered into force 1 July 2006) [ASEAN-Korea FTA].

19. Agreement on Comprehensive Economic Partnership among Member States of the association of Southeast Asia Nations and Japan, signed 31 March 2008 [ASEAN-Japan FTA].

20. Agreement Establishing the ASEAN-Australia-New Zealand Free Trade Area, signed 27 February 2009 (entered into force 1 July 2009) [Australia-ANZ FTA].

21. Ni Komang Erviani and Tassia Sipahutar, 'Anti-WTO activists make their move', The Jakarta Post (Online), 3 December $2013<$ http://www.thejakartapost.com/news/2013/12/03/anti-wto-activists-make-their-move.html>

22. Erwin Renaldi, 'Indonesia's Opposition slams 'lavish' IMF-World Bank meeting in Bali amid quake disaster', ABC News (Online), 10 October 2018 < http://www.abc.net.au/news/2018-10-09/imf-world-bank-meeting-inbali-criticised $/ 10350818>$.

23. 'IMF-World Bank meeting protesters slam Indonesian police for blocking counter-event in Bali', $A B C N e w s$ (Online), 11 October $2018<$ http://www.abc.net.au/news/2018-10-09/imf-world-bank-meeting-in-balicriticised $/ 10350818>$.

24. The Preamble of the WTO., Loc.cit.

25. North American Free Trade Agreement, signed 17 December 1992, [1994] CTS 2 (entered into force 1 January 1994), the preamble ('NAFTA').

26. Muhammad Yunus, Loc.cit.

27. Joseph Stiglitz, 'Addressing Developing Country Priorities and Needs in the Millennium Round' in Roger B Porter and Pierre Sauve (eds), Seattle, the WTO and the Future of the Multilateral Trading System (Harvard University Press, 2000) 55.

28. Paul Krugman and Maurice Obstfeld, International Economic: Theory and Policy (Pearson, 2005) 214-17.

29. Ibid.

30. Adrian Wood, 'Openness and Wage Inequality in Developing Countries: The Latin American Challenge to East Conventional Wisdom' (1997) 11(1) World Bank Economic Review 57, see also Orazio Attanasio, Pinelopi Goldberg and Nina Pavcnik, 'Trade Reforms and Wage Inequality in Colombia' (2004) 74 Journal of Development Economics 366.

31. The Organization for Economic Co-operation and Development, Special Focus: Inequality in Emerging Economies (EEs) (OECD, 2011) 53

32. Ibid 69.

33. United Nations Development Programme, Human Development Report 2015 (United Nations,2015) 58.

34. World Bank, The World Bank Group A to Z (World Bank, 2016) 52.

35. Ibid.

36. Ibid.

37. Hernando De Soto, The Mystery of Capital: Why Capitalism Triumphs In The West and Fails Everywhere Else (Black Swan,2000) 16.

38. David M Trubek, 'The Rule of Law in Development Assistance: Past, Present, and Future' in David Trubek and Alvaro Santos (eds), The New Law and Economic Development: A Critical Appraisal (Cambridge University Press, 2006) 76.

39. Philippa Dee and Christopher Findlay, 'Services in PTAs - donuts or holes?' in Sisira Jayasuria, Donald MacLaren and Gary Magee, Negotiating a Preferential Trading Agreement: Issues, Constraints and Practical Options (Edward Elgar, 2009) 98.

40. APC Subhashini Abeysinghe, 'Services Trade in South Asia: the India-Sri Lanka CEPA' in Pierre Sauvé and Anirudh Shingal, The Preferential Liberalization of Trade in Services: Comparative Regionalism (Edward Elgar, 2004) 312.

41. World Bank, Indonesia Development Policy Review: Enhancing Government Effectiveness in a Democratic and Decentralized Indonesia (The World Bank, 2009) 16.

42. World Justice Project, Indonesia Country Report (World Justice Project, 2015) 24.

43. Klaus Schwab (ed), The Global Competitiveness Report 2016-2017 (World Economic Forum, 2017 ) 204.

44. Daniel S Lev, Hukum dan Politik di Indonesia: Kesinambungan dan Perubahan (LP3ES, 1990$) 77$.

45. Artidjo Alkostar, Negara Tanpa Hukum: Catatan Pengacara Jalanan (Pustaka Pelajar, 2000) 161.

46. FX Adji Samekto, Justice (Not) for All (Kritik terhadap Hukum Modern dalam Perspektif Studi Hukum Kritis) (Yogyakarta: Genta Press,2008) v.

47. Simon Butt, 'Surat Sakti: The Decline of the Authority of Judicial Decisions in Indonesia' (Legal Studies 
Research Paper No. 09/35, Sydney Law School, May 2009) 2.

48. Ibid.

49. Ibid.

50. Edward Aspinall and Greag Fealy, loc.cit.

51. World Bank, op.cit., xvii.

52. Hikmahanto Juwana, 'Penegakan Hukum dalam Kajian Law and Development: Problem dan Fundamen Bagi Solusi di Indonesia’, 2006 (3)2 Indonesian Journal of International Law 224.

53. Ibid.

54. Ibid.

55. Republic of Indonesia Permanent Mission to GATT, Statement of Offers as a Contribution to the Objective of the Trade Negotiation by the Government of Indonesia: Additional Paragraph (21 December 1965) <https:// www.wto.org/english/docs_e/gattbilaterals_e/Kennedy_1964_1967/500147-0006/500147-0006.pdf>.

56. Ibid.

57. Adrian Vickers (ed), A History of Modern Indonesia (Cambridge University Press, 2013) 141.

58. Ibid.

59. Ibid.

60. Thee Kian Wie, 'Policies for Private Sector Development in Indonesia' (ADB Institute Discussion Paper No. 46, 2006) 3.

61. Ibid.

62. LR Kenward, 'Assessing vulnerability to financial crisis: Evidence from Indonesia' (1999) 35(3) Bulletin of Indonesian Economic Studies 95.

63. Thomas Lindblad, 'The political economy of recovery in Indonesia' in Jolle Demmers (et al), Good Governance in the Era of Global Neoliberalism (Taylor and Francis, 2004) 218.

64. World Trade Organisation, Indonesia and the WTO: Indonesia's Uruguay Round Goods Schedules <https:// www.wto.org/english/thewto e/countries e/indonesia e.htm>.

65. Tubagus Feridhanusetyawan and Mari Pangestu, Indonesian Trade Liberalisation: Estimating The Gains $<$ https://www.adelaide.edu.au/cies/documents/papers/iwp0202.pdf $>$.

66. Trade Policy Review Indonesia, WTO Doc WT/TPR/G/184, 23 May 2007 (Report by Indonesia) 19.

67. Margit Molnar and Molly Lesher, 'Indonesia' in Organisation for Economic Co-operation and Development, Globalisation and Emerging Economies: Brazil, Russia, India, Indonesia, China and South Africa (OECD,2008) 338.

68. Ibid.

69. Trade Policy Review Indonesia, WTO Doc WT/TPR/S/278, 6 March 2013 (Report by the Secretariat) 8-9.

70. Ibid.

71. The decision No. 33/PUU-IX/2011 of the Constitutional Court of Indonesia.

72. Law No. 3 of 2014 on Industry, art. 32.

73. Law No. 7 of 2014 on Trade, art. 85

74. Huala Adolf, 'The Indonesian Trade Law of 2014: The Provision on the Annulment of International Trade Agreement' (2015) 10(1) Journal of International Commercial Law and Technology 36.

75. Donghyun Park, 'Prospects of an ASEAN-People's Republic of China Free Trade Area: A Qualitative and Quantitative Analysis' (ADB Economics Working Paper Series 130, 2008) 17.

76. Kementerian Perdagangan Republik Indonesia, Kajian Dampak Kesepakatan Perdagangan Bebas terhadap Daya Saing Produk Manufaktur Indonesia (Kemdag, 2011) 186-187.

77. Ibid.

78. Ibid

79. Ibid

80. International Labour Organisation, Trade and Employment: Country Report for Indonesia ( ILO,2013) ix. 